\title{
Analisa Nilai Resistansi Isolasi Generator 200 MW Dengan Media Pendingin Hydrogen Dan Air Demin
}

\author{
Heri Priagusno. Masdiana ZR, S, Sri Indah Rezkika, Sari Novaliamda \\ Program Studi Teknik Elektro, Fakultas Teknik \\ Universitas Al Azhar Medan \\ Jl. Pintu Air IV No. 214, Kwala Bekala, Medan, Sumatera Utara, Indonesia Telp. (+62)(61)8366679 Kodeposs 20142 \\ e-mail: priagusno@gmail.com
}

\begin{abstract}
Abstrak - Kehandalan pasokan energi listrik sangat dibutuhkan di seluruh negara khususnya di indonesia, untuk menghindari defisitnya pasokan sehingga menimbulkan sistem pemadaman. Untuk itu maka kehandalan sebuah pembangkit listrik sangat diharapkan. Pada sebuah pembangkit listrik, Generator adalah termasuk peralatan yang paling utama. Sebelum generator dioperasikan sudah seharusnya dilakukan pemeriksaan nilai resistansi isolasi sehingga didapatkan nilai minimum sesuai dengan standart IEEE. Penelitian akan dilakukan pada generator 200 MW PLTU Pangkalansusu, pabrikan Beijing Beizhong.co.ltd, yang bermedia pendingin Hydrogen (H2) pada belitan Rotor dan bermedia pendingin Air demin pada belitan Stator. Pada generator jenis ini sering terjadi turunnya nilai resistansi isolasi dibawah nilai minimum sehingga terjadi penundaan untuk pengoperasian Generator dan dapat mengganggu pasokan energi listrik ke jaringan.
\end{abstract}

Kata kunci : Resistansi, isolasi, Air

\begin{abstract}
The reliability of the electrical energy supply is expected in world wide countries, especially in Indonesia, to avoid the deficits supply that cause a blackout in the network. Therefore, the reliability of a power plant is expected. At a power plant, the Generator is among the most important equipment. Before the generator in operated should be checked and measured the value of insulation resistance so that the minimum value obtained in accordance with the IEEE standard. The research will be carried out on a 200MW Pangkalansusu power plant, Beijing Beizhong china manufacturer, which is a Hydrogen (H2) cooling medium in Rotor winding and Demineralisation water cooling medium on Stator winding. In this type of generator there is often occure a decrease in the value of the insulation resistance below to the minimum value, causing a delay for the operation of the generator, and may disrupt the supply of electrical energy to the network.
\end{abstract}

Keywords : $\quad$ Resistance, Insulation, Water

\section{PENDAHULUAN}

Kehandalan pasokan energi listrik sangat dibutuhkan di seluruh negara di dunia. Khususnya di indonesia, masih terjadi gangguan pasokan energi listrik akibat dari defisitnya supply energi listrik dari pembangkit listrik sehingga menyebabkan pemadaman di berbagai daerah Indonesia.

Sekarang ini sedang dilakukan pembangunan pembangkit listrik di seluruh daerah Indonesia oleh pemerintah indonesia dengan program 35.000 MW. Sehingga diharapkan pasokan energi listrik tidak lagi terganggu untuk menerangi seluruh negeri.

Namun tetap saja kehandalan sebuah pembangkit listrik adalah peran yang sangat penting. Banyaknya jumlah pembangkit listrik yang dibangun belum tentu dapat menjamin pasokan energi listrik. Terjaminya kehandalan sebuah pembangkit listrik dan jaringan, akan sangat menjamin tersedianya pasokan energi listrik. Kehandalan sebuah pembangkit listrik ditentukan dengan kehandalan setiap peralatan, baik peralatan utama maupun peralatan bantu.

Generator adalah termasuk peralatan utama yang ada pada sebuah pembangkit listrik. Dari generator inilah dihasilkan energi listrik yang kemudian disalurkan ke jaringan dan dapat dimanfaatkan oleh kita konsumen listrik. Bila kehandalan pada generator terganggu, maka sudah pasti pembangkitan energi listrik terganggu. Nilai minimum resistansi isolasi belitan (winding) sebuah generator sangat menentukan apakah generator siap untuk dioperasikan (energized). Apabila nilai minimum resistansi isolasi belitan (winding) sebuah generator tidak tercapai, maka dikhawatirkan akan terjadi kegagalan isolasi dan dapat merusak belitan generator itu sendiri. 


\section{A. Identifikasi dan Perumusan Masalah}

Seperti kita ketahui bersama, kehandalan pasokan Listrik sangat dibutuhan di Indonesia dan di Sumatera Utara pada khususnya. Menurut data dari PT PLN P3BS (Penyaluran dan Pusat Pengatur Beban Sumatera) pasokan energi Listrik di Sumatera Utara masih mengalami defisit jika terjadi gangguan pada pembangkit listrik, dikarenakan banyak faktor internal seperti gangguan mesin pembangkit maupun gangguan eksternal seperti gangguan pasokan bahan bakar dan gangguan jaringan listrik.

Untuk itu pada kesempatan ini, penulis ingin mengetahui dan mempelajari, bagaimana sebuah nilai resisitansi Isolasi sebuah Generator $200 \mathrm{MW}$ yang berpendingin $\mathrm{H} 2$ dan Air Demin dapat turun dibawah nilai minimum sehingga mengganggu pasokan energi listrik ke jaringan.

\section{B. Tujuan dan Manfaat Penelitian}

Tujuan dilakukanya penelitian ini adalah:

a. Untuk mengetahui penyebab turunnya nilai resistansi Isolasi Generator 200MW di PLTU Pangkalansusu

b. Untuk mendapatkan FDT (Failure Defense Task)

Manfaat setelah dilakukanya penelitian ini adalah:

a. Bertambahnya pemahaman bagi penulis dan pembaca tentang karakteristik Nilai resistansi isolasi sebuah Generator berpendingin $\mathrm{H} 2$ dan Air Demin.

b. Setelah diketahui penyebab turunnya nilai resistansi, permasalahan tidak akan terulang kembali, sehingga tidak terjadi penundaan waktu operasi generator di PLTU Pangkalansusu

c. Dengan dilaksanakanya FDT secara konsisten, kehandalan dari sebuah generator akan terjamin, dan akan terjamin pula kehandalan pasokan energi listrik di Sumatera Utara.

\section{Batasan Penelitian}

Penelitian ini dilakukan pada penurunan nilai resistansi Isolasi Generator $200 \mathrm{MW}$ yang terpasang di Unit 2 PLTU Pangkalansusu, pabrikan Beijing Beizhong.co.Ltd, mempunyai sistem media pendingin Hydrogen (H2) pada Rotor Winding dan media pendingin Air Demin pada Stator Winding. Penelitian dilakukan pada tanggal 10 November 2019 sampai dengan 20 November 2019.

\section{Kerangka Pemikiran Dalam Penelitian}

Menurut literatur mengenai resistansi atau tahanan isolasi suatu penghantar listrik akan mengalami penurunan dari waktu ke waktu, tergantung dari :

1. Kondisi lingkungan,

2. Kelembaban / humidity,

3. Kontaminasi / debu,

4. Temperatur,

5. Gangguan tekanan, dan faktor lainnya.

Dari teori tersebut diatas penulis akan melakukan percobaan dan pengukuran terhadap resistansi isolasi Generator $200 \mathrm{MW}$ di PLTU Pangkalansusu, yang sering mengalami penurunan nilai resistansi sebelum Generator dioperasikan. Sehingga ditemukanya akar penyebab masalah dan segera dilakukan tindakan pencegahan serta perbaikan.

\section{E. Metodologi Penelitian}

Penulisan hasil penelitian ini dilakukan dengan menggunakan beberapa metode, diantaranya sebagai berikut:

- Observasi di lapangan,untuk mengetahui kondisi aktual yang ada saat kejadian.

- Melakukan wawancara dengan Bidang Pemeliharaan dan Operasi

- Melakukan studi literatur dari manual book maupun internet

- Mengolah dan Menganalisa data dengan metode Fishbone, untuk mencari akar masalah yang tepat pada failure mode yang telah ditentukan.

\section{TINJAUAN PUSTAKA}

Bagian Studi Pustaka merupakan bagian optional. Bagian ini membahas teori dasar dari penelitian, yang dianggap penting untuk dikemukakan. Bagian ini juga membahas penelitian-penelitian lain yang relevan dengan penelitian yang dikemukakan pada naskah ini. Bagian Studi Pustaka boleh tidak ada, jika teori dasar/penelitian relevan bisa diintegrasikan pada bagian Pendahuluan.

\section{A. Resistansi Listrik}

Resistansi listrik adalah faktor hambatan terhadap arus listrik yang menyebabkan adanya pengurangan atau pembatasan di dalam suatu aktifitas elektris. Semakin besar resistansi maka akan semakin 
kecil arus yang mengalir, resistansi dipergunakan untuk resistansi isolasi dan semakin kecil resistansi maka akan semakin maksimal arus yang mengalir, resistansi dipergunakan untuk penghantar listrik.

Besaran resistansi adalah bentuk parameter tentang seberapa besar faktor hambatan di antara media-media yang menghantar dalam suatu aktifitas elektris dan dinyatakan di dalam satuan besarannya. Besaran resistansi listrik dinyatakan dalam $\mathbf{\Omega}(\mathbf{O h m})$.

Besarnya hambatan berbanding lurus dengan panjang dan berbanding terbalik dengan luas penampang. Penyataan ini tertuang dalam hukum Pouillet yang ditemukan oleh Claude Pouillet, seorang fisikawan asal negara Prancis. Sumber: Pustaka [4]

$$
R=\rho \frac{l}{A}
$$

Dimana:

$$
\begin{aligned}
& \mathrm{R}=\text { Resistansi Listrik }(\mathrm{Ohm}) \\
& \dot{\rho}=\text { Hambatan jenis }(\Omega . \mathrm{m}) \\
& \mathrm{l}=\text { Panjang Media (meter) } \\
& \text { A = Luas Penampang Media (meter 2) }
\end{aligned}
$$

Berdasarkan rumus diatas, dapat dinyatakan bahwa sebuah kawat (dari jenis yang sama) yang lebih panjang memiliki hambatan listrik yang lebih besar dan sebuah kawat dengan luas penampang lebih besar memiliki hambatan yang lebih kecil.

Tabel 1 Hambatan Jenis

\begin{tabular}{|lclc|} 
Jenis bahan & $\begin{array}{c}\text { Hambatan } \\
\text { jenis }(\Omega \cdot \mathbf{m})\end{array}$ & Jenis bahan & $\begin{array}{c}\text { Hambatan } \\
\text { jenis }(\Omega \cdot \mathbf{m})\end{array}$ \\
\hline Perak & $5,9 \times 10^{-8}$ & Wolfram & $5,5 \times 10^{-5}$ \\
Tembaga & $1,68 \times 10^{-8}$ & Germanium & $4,5 \times 10^{-1}$ \\
Aluminium & $2,65 \times 10^{-8}$ & Silikon & $2,0 \times 10^{-1}$ \\
Platina & $10,6 \times 10^{-8}$ & Kayu & $10-10^{11}$ \\
Baja & $4,0 \times 10^{-7}$ & Karet & $1,0 \times 10^{13}$ \\
Mangan & $4,4 \times 10^{-7}$ & Kaca & $10^{12}-10^{13}$ \\
Nikrom & $1,2 \times 10^{-6}$ & Mika & $2,0 \times 10^{15}$ \\
Karbon & $3,5 \times 10^{-5}$ & Kuarsa & $1,0 \times 10^{18}$ \\
\hline
\end{tabular}

Sumber : Sumber : Pustaka [4]

\section{$B$. Pengukuran Resistansi Isolasi}

Mengetahui besarnya tahanan isolasi dari suatu peralatan listrik merupakan hal yang penting untuk menentukan apakah peralatan tersebut dapat dioperasikan dengan aman. Secara umum jika akan mengoperasikan peralatan tenaga listrik seperti generator, transformator dan motor, sebaiknya terlebih dahulu memeriksa tahanan isolasinya, tidak peduli apakah alat tsb baru atau lama tidak dipakai.
Menurut standar dari IEEE Std 43-2000 "Recommended Practice for Testing Insulation Resistance of Rotating Machinery" nilai resistansi isolasi minimum adalah $\mathrm{IR}=\mathrm{KV}+1$

Tabel 2 Resistansi Isolasi Minimum

\begin{tabular}{|l|l|}
\hline \multicolumn{1}{|c|}{$\begin{array}{c}\text { Minimum insulation } \\
\text { resistance }\end{array}$} & \multicolumn{1}{|c|}{ Test specimen } \\
\hline$I R_{1 \min }=k V+1$ & $\begin{array}{l}\text { For most windings made before about 1970, all field windings, and } \\
\text { others not described below }\end{array}$ \\
\hline$I R_{1 \min }=100$ & $\begin{array}{l}\text { For most dc armature and ac windings built after about 1970 (form- } \\
\text { wound coils) }\end{array}$ \\
\hline$I R_{1 \min }=5$ & $\begin{array}{l}\text { For most machines with random-wound stator coils and form- } \\
\text { wound coils rated below } 1 \mathrm{kV}\end{array}$ \\
\hline
\end{tabular}

\section{MEtode}

\section{A. Pengambilan Data Penelitian}

Pengukuran resistansi isolasi dilakukan pada titik netral Generator, tepatnya pada Neutral Generator Resistance (NGR). Pemilihan titik pengukuran dengan harapan Titik netral dari generator mewakili seluruh belitan (winding) Generator phasa R, S, T. Pengukuran dilakukan antara titik Netral dengan titik Grounding, sehingga didapatkan nilai Resistansi isolasi dari Generator.

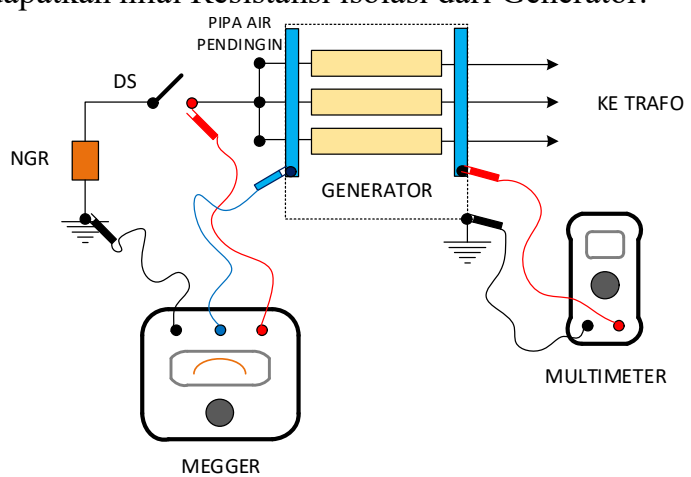

Gambar 3.1 Titik Pengukuran

Berikut adalah lankah - langkah yang dilakukan untuk pengukuran resistansi isolasi Generator:

1. Posisikan Open DS (Disconnecting Switch) NGR

2. Pastikan generator aman dari manusia

3. Sambungkan kabel Merah dari Megger ke titik Netral Generator

4. Sambungkan kabel Hitam megger ke titik Grounding sekitar

5. Sambungkan kabel Biru dari Megger ke titik Header pipa pendingin air sebagai kompensasi pengukuran arus bocor.

6. Pilih selector tegangan ke 2500 volt

7. Tekan tombol TEST 
B. Pengujian pertama ( Berdasarkan Koduktivitas air)

1. Pada pengukuran pertama, dilakukan pada pukul 10.00 WIB pada cuaca yang cerah, didapatkan nilai resistansi isolasi Generator sebesar $6 \mathrm{Mohm}$. Nilai ini belum memenuhi nilai standar minimum pada tegangan kerja Generator $15,75 \mathrm{KV}$ seharusnya nilai minimum sebesar 17 Mohm.

2. Dilakukan pengukuran Nilai resistansi Pipa air demin pendingin terhadap Grounding, didapatkan nilai resistansi sebesar $15 \mathrm{Kohm}$. Nilai standar menurut Manual Book generator adalah sebesar $30 \mathrm{Kohm}$.

3. Dilakukan pemeriksaan konduktivitas air demin pendingin didapatkan konduktivitas sebesar $2,1 \mu \mathrm{s} / \mathrm{cm}$.

4. Dilakukan treatment air demin pendingin dengan sistem flushing yaitu dengan mengganti air demin pendingin secara pengisian tanki sambil membuang air dalam tanki.

5. Setelah konduktivitas $0,7 \mu \mathrm{s} / \mathrm{cm} 2$, dilakukan pengukuran kembali dan diperoleh nilai resistansi isolasi mengalami kenaikan sebesar 10,7 Mohm, namun masih belum memenuhi nilai standar minimum.

6. Konduktivitas air dijaga terus dibawah < $1 \mu \mathrm{s} / \mathrm{cm} 2$.

Tabel 3 Pengukuran berdasarkan Konduktivitas air

\begin{tabular}{|r|r|r|}
\hline $\begin{array}{c}\text { Conductivity } \\
(\boldsymbol{\mu S} / \mathbf{c m} \mathbf{)})\end{array}$ & $\begin{array}{c}\text { Resistansi } \\
\text { Pipa }(\mathbf{K o h m})\end{array}$ & $\begin{array}{c}\text { Resistansi } \\
\text { Isolasi (Mohm) }\end{array}$ \\
\hline 2,1 & 20,4 & 5,5 \\
\hline 1,5 & 23,3 & 6,9 \\
\hline 1,1 & 29,8 & 7,4 \\
\hline 0,8 & 33,4 & 9,8 \\
\hline 0,7 & 42,6 & 10,7 \\
\hline
\end{tabular}

C. Pengujian Kedua (berdasarkan Cuaca/Humidity) :

1. Dilakukan pengukuran kembali pada kondisi cuaca sedikit hujan

2. Pada area Trafo GT pada pukul 08.00 WIB dilakukan pengukuran Humidity didapatkan $68 \%$ dan temperatur $28^{\circ} \mathrm{C}$

3. Dilakukan pengukuran Resisitansi isolasi Generator didapatkan nilai 6,5Mohm

4. Dilakukan pengukuran setiap 2 jam sampai pukul 16.00 WIB, mengalami kenaikan resistansi isolasi, namun belum mencapai nilai standar minimum.

5. Pada keesokan harinya dilakukan pengukuran kembali pada cuaca yang cerah
6. Pada area Trafo GT pada pukul 08.00WIB dilakukan pengukuran Humidity didapatkan $65 \%$ dan temperatur $29^{\circ} \mathrm{C}$

7. Dilakukan pengukuran Resisitansi isolasi Generator didapatkan nilai 6,8Mohm

8. Dilakukan pengukuran setiap 2 jam sampai pukul 16.00 WIB

9. Pada siang hari pukul 12.00 WIB mengalami kenaikan resistansi isolasi yang signifikan sebesar $23 \mathrm{Mohm}$.

10. Dilakukan pemeriksaan pada setiap sambungan Generator ke Trafo yaitu pada trafo GT, trafo UAT dan Trafo excitasi.

11. Ketika dilakukan pemeriksaan pada koneksi IPB ke trafo GT, ditemukan sedikit air didalam rubber flexible joint, ternyata terdapat kebocoran pada rubber flexible trafo GT.

12. Dilakukan pembersihan, kemudian dilakukan heating/pengeringan dengan lampu Halogen 1000W hingga dipastikan kering.

13. Dilakukan pengukuran kembali didapatkan nilai resistansi yang relatif stabil setiap 2 jam sebesar 24-25 Mohm, sudah memenuhi nilai standar dan generator siap untuk dioperasikan.

Tabel 4 Pengukuran pada Kondisi Cuaca Sedikit Hujan

\begin{tabular}{|c|r|r|r|}
\hline $\begin{array}{c}\text { Pukul } \\
\text { (WIB) }\end{array}$ & $\begin{array}{c}\text { Humidity } \\
\mathbf{( \% )}\end{array}$ & $\begin{array}{c}\text { Temperatur } \\
\left({ }^{\mathbf{}} \mathbf{C}\right)\end{array}$ & $\begin{array}{c}\text { Resistansi } \\
\text { Isolasi } \\
(\mathbf{M o h m})\end{array}$ \\
\hline 08.00 & 68 & 28 & 6,5 \\
\hline 10.00 & 65 & 29 & 7,8 \\
\hline 12.00 & 66 & 30 & 8,1 \\
\hline 14.00 & 65 & 30 & 9,6 \\
\hline 16.00 & 65 & 29 & 9,4 \\
\hline
\end{tabular}

Tabel 5 Pengukuran pada Kondisi Cuaca Cerah

\begin{tabular}{|r|r|r|r|}
\hline $\begin{array}{r}\text { Pukul } \\
\text { (WIB) }\end{array}$ & $\begin{array}{c}\text { Humidity } \\
(\mathbf{\%})\end{array}$ & $\begin{array}{c}\text { Temperatur } \\
\left({ }^{\mathbf{0}} \mathbf{C}\right)\end{array}$ & $\begin{array}{c}\text { Resistansi } \\
\text { Isolasi } \\
(\mathbf{M o h m})\end{array}$ \\
\hline 08.00 & 65 & 29 & 6,8 \\
\hline 10.00 & 55 & 31 & 15,6 \\
\hline 12.00 & 43 & 36 & 23,7 \\
\hline 14.00 & 42 & 35 & 25,4 \\
\hline 16.00 & 50 & 35 & 24,8 \\
\hline
\end{tabular}

D. Pengujian Ketiga ( Setelah Perbaikan Kebocoran Rubber Flexible)

1. Setelah dilakukan perbaikan kebocoran pada Rubber fexible dan diberikan pelapisan dengan plastik sementara, dilakukan 
pengukuran kembali pada kondisi cuaca cerah

2. Pada area Trafo GT pada pukul 08.00WIB dilakukan pengukuran Humidity didapatkan $63 \%$ dan temperatur $29^{\circ} \mathrm{C}$

3. Dilakukan pengukuran Resisitansi isolasi Generator didapatkan nilai 22,4 Mohm

4. Dilakukan pengukuran setiap 2 jam sampai pukul 16.00 WIB

5. Nilai resistansi isolasi cenderung stabil setiap 2 jam nya.

Tabel 6 Pengukuran setelah perbaikan

\begin{tabular}{|r|r|r|l|}
\hline $\begin{array}{l}\text { Pukul } \\
\text { (WIB) }\end{array}$ & $\begin{array}{l}\text { Humidity } \\
(\%)\end{array}$ & $\begin{array}{l}\text { Temperatur } \\
\left({ }^{\circ} \mathbf{C}\right)\end{array}$ & $\begin{array}{l}\text { Resistansi } \\
\text { Isolasi } \\
\text { (Mohm) }\end{array}$ \\
\hline 08.00 & 63 & 29 & 22,4 \\
\hline 10.00 & 53 & 31 & 22,9 \\
\hline 12.00 & 44 & 36 & 24,8 \\
\hline 14.00 & 43 & 35 & 25,3 \\
\hline 16.00 & 51 & 35 & 24,6 \\
\hline
\end{tabular}

\section{HASIL DAN PEMBAHASAN}

Untuk analisa permasalahan ini dilakukan dengan metode FISHBONE, berikut ini adalah pemilihan kemungkinan penyebab gangguan dengan $4 \mathrm{M}$ dan $1 \mathrm{E}$ (Metode, Machine, Material, Men, Environment)

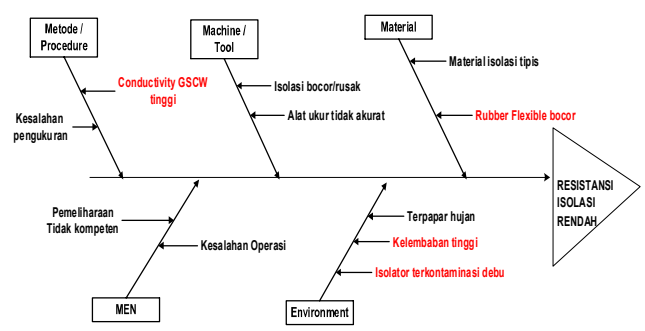

Gambar 1 Fishbone diagram gangguan

Dengan didapatkanya data-data hasil pengukuran pada penelitian, maka dapat dilakukan pembahasan dan diselaraskan dengan kemungkinan penyebab yang dituangkan dalam metode Fishbone.

\section{A. Metode/Procedure}

Metode pengukuran yang dilakukan oleh bidang pemeliharaan Listrik sudah sesuai dengan IK (Instruksi Kerja), dan titik pengukuran dilakukan sesuai dengan metode pengukuran Winding/belitan.
Sehingga permasalahan pada point ini dapat dieliminasi.

Ketika dilakukan pengukuran pada kondisi conductivity dari air GSCW lebih dari $1 \mu \mathrm{s} / \mathrm{cm}$, maka nilai resistansi dari isolasi header pipa GSCW terhadap grounding akan kurang dari $30 \mathrm{~K} \Omega$. Sehingga permasalahan pada point ini dapat dipertimbangkan karena dapat mempengaruhi turunya nilai resistansi.

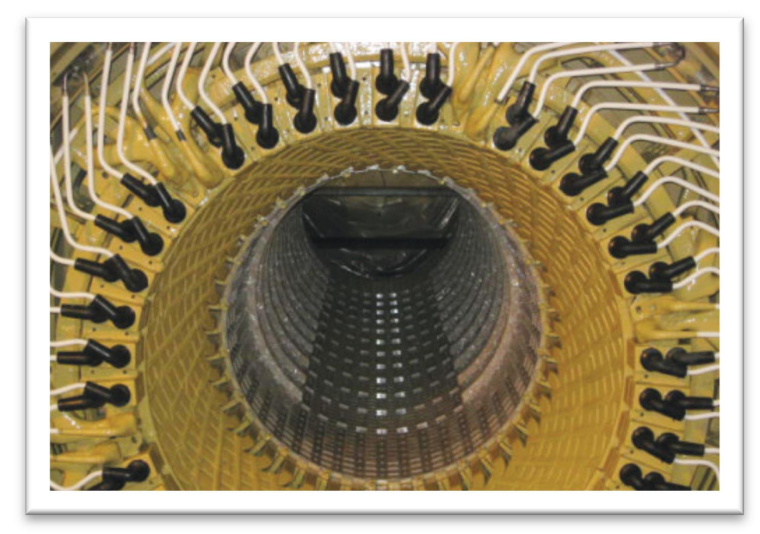

Gambar .1 Distribusi pipa air demin pendingin pada belitan generator

B. Machine / Tool

Tool yang digunakan untuk mengukur tahanan isolasi menggunakan isolation tester dengan merek MEGGER MIT1025 tidak diragukan kualitasnya dan baru diadakan di tahun 2015, sehingga permasalahan pada point ini dapat dieliminasi.

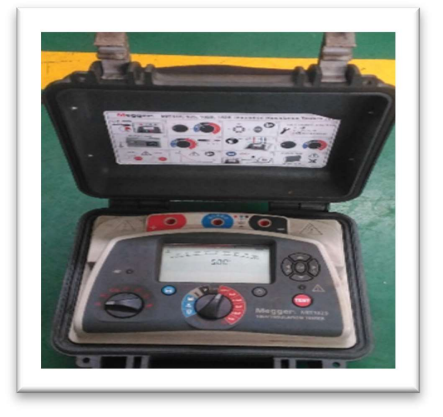

Gambar.2 Megger MIT1025

C. Men

Pengukuran dilakukan oleh Teknisi Pemeliharaan Listrik yang sudah mendapatkan training dari manufacture/pabrikan Insulation tester (MEGGER) dan sudah kompeten melakukan pengukuran. Permasalahan ini dapat dieliminasi. 


\section{Material}

Ketika dilakukan pemeriksaan pada koneksi IPB ke trafo, ditemukan sedikit air didalam rubber flexible joint. Material untuk rubber flexible IPB pada GT ditemukan sudah bocor dan sudah ditambal menggunakan red silicone pasta.

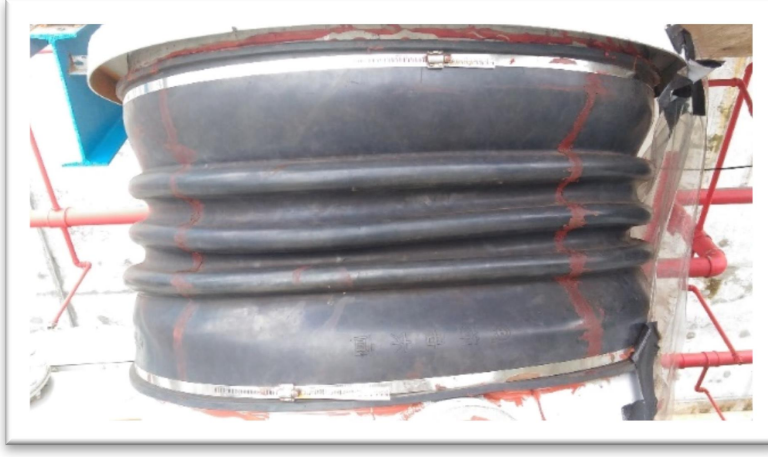

Gambar 3 Rubber flexible GT

Sehingga permasalahan pada point ini dapat dipertimbangkan, karena dapat menyebabkan kontaminasi maupun meningkatkan kelembaban pada koneksi trafo.

\section{E. Environment}

Kondisi rubber flexible IPB pada GT masih ada kemungkinan terpapar air hujan karena canopy yang terpasang tidak melindungi seluruh rubber flexible.

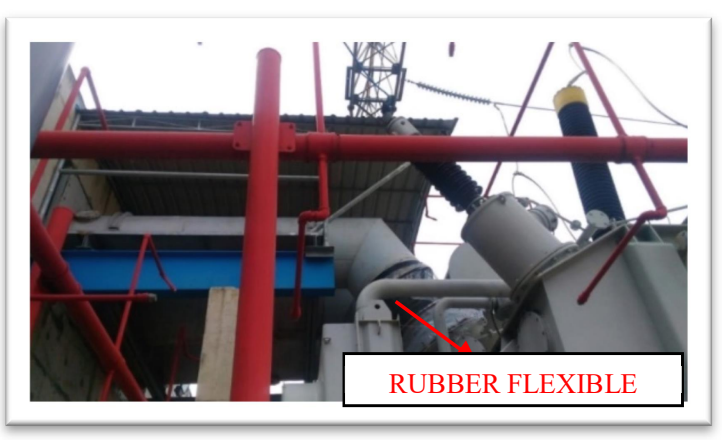

Gambar 4 Kondisi Canopy

Di dalam sebuah IPB terdapat beberapa isolator penyangga penghantar IPB itu sendiri, isolator tersebut menjadi penghalang antara penghantar dan body IPB (ground). Jika isolator tersebut terkontaminasi debu, maka dapat mengakibatkan turunya nilai tahanan isolasi.

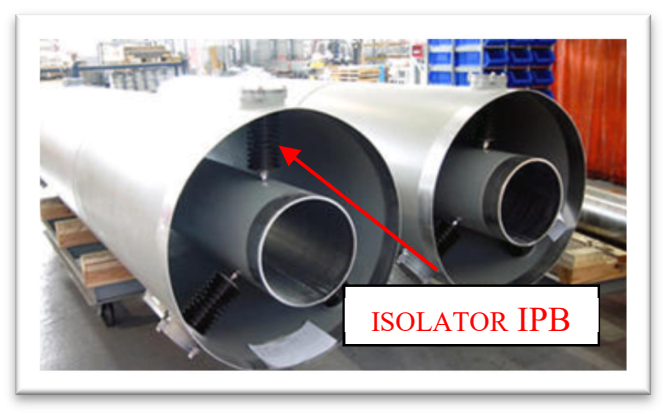

Gambar .5 Isolator IPB

\section{KESIMPULAN}

Setelah dilakukan analisa dan pembahasan menggunakan metode Fisbone, maka dapat diambil kesimpulan bahwa rendahnya nilai resistansi isolasi pada Generator Unit 2 PLTU Pangkalansusu dapat disebabkan oleh beberapa faktor yaitu Kondisi kelembaban pada sambungan Generator ke Trafo melalui penghantar IPB, Kondisi conductivity air demin pendingin GSCW yang tinggi (diatas $1 \mu \mathrm{s} / \mathrm{cm}$ ), Kontaminasi isolator didalam IPB.

Untuk mencegah terjadinya gangguan rendahnya nilai resistansi isolasi Generator maka perlu tindakan pencegahan atau sering disebut Failure Defense Task (FDT) sebagai berikut: Menjaga conductivity air demin pendingin GSCW dibawah $1 \mu \mathrm{s} / \mathrm{cm}$, Melakukan Cleaning dan inspeksi semua isolator di dalam IPB, Melakukan heating pada joint GT dengan lampu Halogen 1000W, sebelum generator akan dioperasikan.

\section{DAFTAR PUSTAKA}

[1] Beijing Jisi Electric Co.Ltd. July 2007, 220MW Turbin Generator-Q32J JT, Manual Book Generator

[2] IEEE 43-2000, Standar pengukuran Nilai Resistansi Isolasi

[3] F0003S-00-D0301-Generator Layout Installation, Drawing layout sambungan Generator ke Trafo,

[4] B.L Theraja, A.K Theraja, "A Text Book Of Electrical Technology"

[5] Wijaya, Mochtar, 2001, "Dasar-Dasar Mesin Listrik”, Jakarta, Penerbit Djambatan, 